\title{
ALGAL DISTRIBUTION AND ITS ABUNDANCE IN PUTHALAM SALTWORKS, KANYAKUMARI DISTRICT, TAMIL NADU
}

\author{
Laila banu, N.R ${ }^{1 *}$. and M. Reginald ${ }^{2}$ \\ ${ }^{1}$ Department of Botany, S.T. Hindu College, Nagercoil - 629002. \\ ${ }^{2}$ Department of Botany, Scott Christian College (Autonomous), Nagercoil - 629003. \\ *E.mail: laila_n_banu@yahoo.com
}

\section{ABSTRACT}

Saltworks are important wetlands and exposed to wide range of environmental stress and perturbations. Fluctuations of salinity, brine chemistry and nutrient status leads to variation in microalgal population. The typical saltworks Sri Sankara Allom, Puthalam was chosen for the study. The investigation was aimed to list out the microalgae and calculates their abundance. The work was done in different seasons (I, II, III and IV) of the study period (March 2009 to February 2010). The reservoir pond showed major variation among micro algal species but it was low in condenser pond. Only two micro algal species were observed in crystallizer pond. A gradual reduction in number of micro algal species was observed with an increase in salinity. With regard to crystallizer, Dunaliella was the dominant one throughout the study period.

Keywords: Abundance, condenser, crystallizer, microalgae, reservoir, saltworks.

\section{INTRODUCTION}

Saltpans are one of the hypersaline extreme environments. Among halophilic microorganisms, bacteria, cyanobacteria, green algae, fungi and diatoms are abundant in saltpans (Das Sarma and Arora, 2002) and form a biological pad (Zhiling and Guangyu, 2009). They withstand extreme saline conditions and regulate the osmotic pressure, thereby resisting the denaturing effects of salt in their environment (Kerkar, 2004).

In Kanyakumari District eight saltpan industries are involved in the salt production process. In these, the typical tropical saltworks Sri Sankara Allom Salt Factory, Puthalam, Kanyakumari District in South Tamil Nadu is situated between Manakudy seacoast and Puthalam village. This allom was the first to use sub-soil brine for salt production. The total area of this salt work is 24.88 ha. It is situated $13 \mathrm{~km}$ south east of Nagercoil and $5 \mathrm{~km}$ north of Kanyakumari at $8^{\circ} 04^{\prime} \mathrm{N}$ latitude and $77^{\circ} 68^{\prime}$ east longitude. This is one of the best salt producing area in Kanyakumari District and also contains rich plankton community. The aim of this work is to list out the microalgae present in the various ponds of saltworks and also calculate the abundance of phytoplankton.

\section{MATERIALS AND METHODS}

\subsection{Algal sampling and analysis}

For the study, the microalgae and its abundance (\%) were studied throughout the study period. The investigation period (March 2009 to February 2010) was divided into four seasons viz. summer (March, April and May), autumn (June, July and August), spring (September, October and November) and winter (December, January and February). The collection was made in early morning. A circular hand net of $1 / 2 \mathrm{~m}$ length with 15 $\mathrm{cm}$ mouth diameter of a mesh size of $2 \mu$ was used for the collection of phytoplankton samples by filtering 100 litres of water. Then the filtrate was put into clean labeled plastic container and also fixed in Lugol's iodine soon after the collection for further analysis. The fixed samples were transferred to the laboratory and kept undisturbed until analysis. Drop method was applied for counting and identification of phytoplankton species from different samples (APHA, 1992). The cell number was determined by direct counting under a compound microscope. Then they were identified, based on standard monographs (Venkataraman, 1939; Prescott, 1962; Desikachary, 1986). Name, systematic position and the abundance of the microalgae (declared as \% abundance/unit area) were tabulated.

\section{RESULTS}

The abundance of phytoplankton showed fluctuation during different seasons of the study period. In general, the reservoir pond showed the higher average population more than the other studied (condenser and crystallizer) ponds.

During the present study a gradual reduction in number of microalgal species were 
observed with an increase in salinity. Totally 18 different genera of phytoplankton were identified in the reservoir pond (Table 1). Among these Bacillariophyta contributed more number of genera (7 numbers) followed by Cyanophyta (6 numbers), Chlorophyta (3 numbers) and Dinophyta (2 numbers) (Tables 2 and 3). It is clearly evident and notable that microalgal species like Nitzschia was recorded only in season II, Cosinodiscus in season III, Chroococcus in season I and Peridinium in season IV. But Gleocapsa and Exuviella were recorded in season III and IV. And also it is a point of consideration.

Table 1. Distribution of algal species identified and its abundance (\%) in the reservoir pond of Puthalam saltworks during March 2009 to Feb. 2010.

\begin{tabular}{|c|c|c|c|c|c|c|c|}
\hline \multirow[b]{2}{*}{$\begin{array}{l}\text { S. } \\
\text { No. }\end{array}$} & \multirow[b]{2}{*}{ Name } & \multicolumn{2}{|c|}{ Systematic position } & \multicolumn{4}{|c|}{ Abundance (\%) } \\
\hline & & Order & Division & $\begin{array}{c}\text { Season } \\
\text { I }\end{array}$ & $\begin{array}{c}\text { Season } \\
\text { II }\end{array}$ & $\begin{array}{c}\text { Season } \\
\text { III }\end{array}$ & $\begin{array}{c}\text { Season } \\
\text { IV }\end{array}$ \\
\hline 1. & Pleurosigma sp. & Naviculales & Bacillariophyta & 45.62 & 7.11 & 17.72 & 56.73 \\
\hline 2. & Navicula sp. & Naviculales & Bacillariophyta & 0.55 & 14.50 & 15.82 & 7.24 \\
\hline 3. & Cyclotella sp. & Centrales & Bacillariophyta & 0.52 & 2.87 & 2.94 & 4.51 \\
\hline 4. & Pinnularia sp. & Naviculales & Bacillariophyta & 0.34 & 0.95 & 2.77 & -- \\
\hline 5. & Amphora sp. & Naviculales & Bacillariophyta & 0.09 & 0.96 & 4.93 & 0.85 \\
\hline 6. & Nitzschia sp. & Nitzschiales & Bacillariophyta & -- & 2.19 & -- & -- \\
\hline 7. & Coscinodiscus sp. & Coscinodiseales & Bacillariophyta & -- & -- & 1.31 & -- \\
\hline 8. & Dunaliella sp. & Volvocales & Chlorophyta & 41.86 & 20.52 & 21.0 & 5.64 \\
\hline 9. & Chlorella sp. & Chlorellales & Chlorophyta & 3.07 & 0.96 & 1.64 & 6.86 \\
\hline 10. & Closterium sp. & Desmidiales & Chlorophyta & 0.14 & 0.41 & -- & 0.75 \\
\hline 11. & Oscillatoria sp. & Nostocales & Cyanophyta & 7.35 & 26.40 & 26.53 & 10.72 \\
\hline 12. & Spirulina sp. & Nostocales & Cyanophyta & 0.06 & 0.42 & 3.80 & 0.85 \\
\hline 13. & Lyngbya sp. & Nostocales & Cyanophyta & 0.34 & 22.71 & -- & 4.33 \\
\hline 14. & Anabaena sp. & Nostocales & Cyanophyta & -- & 0.54 & 1.38 & 0.09 \\
\hline 15. & Gloeocapsa sp. & Chroococales & Cyanophyta & -- & -- & 0.09 & 1.03 \\
\hline 16. & Chroococcus sp. & Chroococales & Cyanophyta & 0.06 & -- & -- & -- \\
\hline 17. & Exuviella sp. & Gleodinales & Dinophyta & -- & -- & 0.08 & 0.47 \\
\hline 18. & Peridinium sp. & Peridiniales & Dinophyta & -- & -- & -- & 0.65 \\
\hline
\end{tabular}

Each value is a mean of four data; -- Absent

Table 2. List of microalgae and its abundance (\%) in the condenser pond of Puthalam saltworks during March 2009 to February 2010.

\begin{tabular}{|c|c|c|c|c|c|c|c|}
\hline \multirow{2}{*}{$\begin{array}{c}\text { S. } \\
\text { No }\end{array}$} & \multirow[b]{2}{*}{ Name } & \multicolumn{2}{|c|}{ Systematic position } & \multicolumn{4}{|c|}{ Abundance (\%) } \\
\hline & & Order & Division & $\begin{array}{c}\text { Season } \\
\text { I }\end{array}$ & $\begin{array}{c}\text { Season } \\
\text { II }\end{array}$ & $\begin{array}{c}\text { Season } \\
\text { III }\end{array}$ & $\begin{array}{c}\text { Season } \\
\text { IV }\end{array}$ \\
\hline 1. & Pleurosigma sp. & Naviculales & Bacillariophyta & 2.23 & 4.98 & 1.20 & 4.93 \\
\hline 2. & Navicula sp. & Naviculales & Bacillariophyta & -- & -- & 0.31 & 0.70 \\
\hline 3. & Pinnularia sp. & Naviculales & Bacillariophyta & 0.04 & -- & 0.12 & -- \\
\hline 4. & Dunaliella sp. & Volvocales & Chlorophyta & 79.10 & 14.94 & 98.05 & 90.14 \\
\hline 5. & Synechococcus sp. & Synechococcales & Cyanophyta & 18.30 & 78.16 & 0.03 & 1.76 \\
\hline 6. & Chroococcus sp. & Chroococales & Cyanophyta & 0.32 & 2.04 & 0.28 & -- \\
\hline 7. & Peridinium sp. & Peridiniales & Dinophyta & -- & -- & -- & 2.46 \\
\hline
\end{tabular}

Each value is a mean of four data; -- Absent

Table 3. Phytoplankton and its abundance (\%) in the crystallizer pond of Puthalam saltworks during March 2009 to February 2010.

\begin{tabular}{|c|c|c|c|c|c|c|c|}
\hline \multirow[b]{2}{*}{$\begin{array}{c}\text { S. } \\
\text { No. }\end{array}$} & \multirow[b]{2}{*}{ Name } & \multicolumn{2}{|c|}{ Systematic position } & \multicolumn{4}{|c|}{ Abundance (\%) } \\
\hline & & Order & Division & $\begin{array}{c}\text { Season } \\
\text { I }\end{array}$ & $\begin{array}{c}\text { Season } \\
\text { II }\end{array}$ & $\begin{array}{c}\text { Season } \\
\text { III }\end{array}$ & $\begin{array}{c}\text { Season } \\
\text { IV }\end{array}$ \\
\hline 1. & Dunaliella sp. & Volvocales & Chloro & 96.21 & 98.73 & 98.96 & 99.37 \\
\hline 2. & Chroococcus sp. & Chroococales & Cyanophyta & 3.79 & 1.27 & 1.04 & 0.63 \\
\hline
\end{tabular}

Each value is a mean of four data 
Only seven genera from three divisions were identified in the condenser pond. Dunaliella was dominant in all the seasons except season II. At the same time, Synechococcus had dominated only in season II. Peridinium, one of the members of Dinophyta was recorded only in season IV which is a notable fact. In the crystallizer pond only two genera were found in one in each of the divisions Chlorophyta and Cyanophyta. Dunaliella was the dominant one in all the seasons during the study and registered the abundance of 96.21 (season I), 98.73 (season II), 98.96 (season III) and $99.37 \%$ (season IV) respectively. The another species Chroococcus showed the lowest abundance of 3.79, 1.27, 1.04 and $0.63 \%$ in the seasons.

The population size of different groups and species of phytoplankton at various ponds during different seasons were highly variable. Higher abundance of phytoplankton in all ponds was recorded during season IV.

\section{DISCUSSION}

The population density estimated in reservoir pond of Puthalam saltworks showed the major variation among microalgal species. Examination of phytoplankton population revealed that the density of phytoplankton varied in relation to salinity. Salinity showed a significant relation with Bacillariophyceae and Cyanophyceae which was abundant in low salinity ponds followed by Chlorophyta and Dinophyta. These results are agreement with the results of Reginald (2003).

Diatoms were abundant and most frequently encountered in the microscopic survey of this study. The cyanobacterial species occupied the second dominant position. It was in accordance with the findings of Oren (2009) and Khan et al. (2009).

In the reservoir pond, among the most abundant microalgae identified were species of the genera Pleurosigma, Navicula, Cyclotella, Amphora, Dunaliella, Chlorella, Oscillatoria and Spirulina. Although Bacillariophyta were dominant in respect to species numbers, Cyanophyta and Chlorophyta type phytoplankton were registered in terms of population density (Elif and Arif, 2010). Blooming of phytoplankton occur in season II induced by changes in temperature and nutrients supply during summer.

The salinity was higher in the condenser pond than the reservoir and also condenser pond receives brine from the reservoir. The population density and species abundance were very low in the condenser pond of Puthalam saltworks. The presence of Pleurosigma, Navicula, Dunaliella and Chroococcus throughout the study period indicates that they can tolerate wide fluctuations in salinity.

One organism that is the cyanobacterium Synechococcus was present in the condenser pond which was not observed in reservoir pond and crystallizer pond throughout the study period. It is a slime producing algae grow and reproduce best in intermediate salinities (Oren, 2000) but they do not survive in crystallizers. Synechococcus and Dunaliella species are the key organisms in condenser pond and common in most solar saltworks. Dunaliella species could tolerant extreme high salinity and they become the dominant species.

Increased salinity in the crystallizer ponds has eliminated some non-tolerant species. There are only two micro algal species (Dunaliella and Chroococcus) were noticed even in the crystallizer pond. The chlorophycean member Dunaliella species was present in all ponds and constituted the bulk of phytoplankton in the crystallizer ponds. The same effect in Thamaraikulam saltworks of Kanyakumari District, South Tamil Nadu was observed in the past by Reginald (2003). According to Davis (2009) the algal species of Dunaliella remain alive in high salinity and gradually change colour to bright orange-red, enlarge, become spherical and accumulate glycerol and beta carotene.

From these observations, the present study of surveying in Puthalam saltworks gives an idea about microalgal population, provide first hand knowledge about the co-existence of various phytoplankton to the peculiar environment offered by the solar saltpan, evaluate their interaction among themselves and provide useful information regarding their nature in various salinities of the ponds in order to survive for quality salt production. Another important fact learned through this study was, most of the marine algae prefer shelf-shade for its survival in salinity.

\section{ACKNOWLEDGEMENT}

The authors record their thanks to Department of Botany \& Research Centre, Scott Christian College (Autonomous), Nagercoil for the facilities provided regarding this work.

\section{REFERENCES}

APHA, (1992). Standard methods for the examination of water and waste water, $19^{\text {th }}$ edition American Public Health Association, p. 472. 
Das Sarma, S. and P. Arora. (2002). HalophilesEncyclopedia of Life Sciences, Vol. 8. Nature Publishing Group, London.

Davis, J.S., (2009). Management of biological systems for continuously operated solar saltworks. Global NEST, 11(1): 73-78.

Desikachary, T.V., (1986). Atlas of diatoms: Plates 401-621. 1 ${ }^{\text {st }}$ Edition, Madras Science Foundation (Madras).

Elif, N.S. and G. Arif, (2010). Functional classification and composition of phytoplankton in Liman lake. Turk. J. Fisher. Aqua. Sci. 10: 53-60.

Kerkar, S., 2004. Ecology of hypersaline microorganisms. In: Marine microbiology: Facets \& Opportunities, Ramaiah, N. (ed.), National Institute of Oceanography, Goa, p. 3747.

Khan, S.A., Rashmi, M.Z. Hussain, S. Prasad and U.C. Banerjee, (2009). Prospects of biodiesel production from microalgae in India. Renew. Sustain. Energy Rev. 13: 2361-2672.

Oren, A. (2000). Salts and brines. In: Whitton B.A., Potts, M. (eds.). Ecology of Cyanobacteria: their diversity in time and space. Kluwer Academic Publishers, Dordrecht, p. 281-306.

Oren, A. (2009). Saltern evaporation ponds as model systems for the study of primary production processes under hypersaline conditions. Aquat. Microb. Ecol. 56: 193-204.

Prescott, G.W., (1962). Algae of the Western Great Lakes Area, $2^{\text {nd }}$ Ed. Brown Co., Dubuque, Low, p. 1-997.

Reginald, M., (2003). Studies on salt tolerant microalgae in relation to their applied physiology for Biotechnology. Ph.D. Thesis, Manonmaniam Sundaranar University, Tirunelveli, Tamil Nadu, India.

Venkataraman, G., (1939). A systematic account of some South Indian diatoms. In: Proc. Ind. Acad. Sci. 10(6): 293-370.

Zhiling, J. and Y. Guangyu, (2009). The promotion of salt quality through optimizing brine concentration a new technique "Bidirectional brine concentration." Global NEST, 11(1): 5863. 